\title{
Deglacial-Holocene environmental changes at the Pacific entrance of the Strait of Magellan
}

\author{
Naomi Harada ${ }^{\mathrm{a}, *}$, Ulysses Ninnemann ${ }^{\mathrm{b}}$, Carina B. Lange ${ }^{\mathrm{c}}$, Margarita E. Marchant ${ }^{\mathrm{d}}$, Miyako Sato ${ }^{\mathrm{a}}$, \\ Naokazu Ahagon ${ }^{\mathrm{e}}$, Silvio Pantoja ${ }^{\mathrm{c}}$ \\ a Research Institute for Global Change, Japan Agency for Marine-Earth Science and Technology, 2-15 Natsushima-cho, Yokosuka, Japan \\ b Department of Earth Science and Bjerknes Centre of Climate Research, University of Bergen, Allegaten 55, Bergen, N-5007, Norway \\ c Department of Oceanography and Center for Oceanographic Research in the Eastern South Pacific (COPAS), University of Concepción, Casilla 160-C, Concepción, Chile \\ d Department of Zoology, University of Concepción, Casilla 160-C, Concepción, Chile \\ e Kochi Institute for Core Sample Research, Japan Agency for Marine-Earth Science and Technology, Nankoku, Japan
}

\section{A R T I C L E I N F O}

\section{Article history:}

Received 24 October 2011

Received in revised form 3 February 2013

Accepted 20 February 2013

Available online 4 March 2013

\section{Keywords:}

Biogenic components

$\delta^{13} \mathrm{C}$

$\delta^{15} \mathrm{~N}$

Planktic foraminifera

Alkenone

Sea surface temperature

Southern Patagonia

\begin{abstract}
A B S T R A C T
We show environmental and nitrogen cycle changes between 13 and $2.5 \mathrm{kyr}$ BP (from the latest deglaciation to the Holocene) based on biogeochemical records in a sediment core from the Pacific entrance of the Strait of Magellan. Organic carbon, total nitrogen, and $C_{37}$ alkenone contents were low during 13-9 kyr BP but increased rapidly at $8 \mathrm{kyr} \mathrm{BP}$. The relative contribution of tetra-unsaturated $\mathrm{C}_{37}$ alkenone, used as a salinity proxy, suggests low salinity during 13-9 kyr BP changing to high salinity at 8 kyr BP. Planktic foraminifer data showed that Globigerina bulloides was more abundant during the deglacial-early Holocene than in the mid-late Holocene, whereas abundances of Neogloboquadrina pachyderma showed the opposite pattern. This evidence plus biogenic opal data suggest that sea level rose, surface waters were relatively stratified, and in situ productivity was low except for organisms with opal tests from 13 to 9 kyr BP. Bulk $\delta^{15} \mathrm{~N}$ values were high $(9-11 \%)$ relative to present-day values during the deglacial-early Holocene, with consistently lower values $(\sim 7 \%)$ after $\sim 8 \mathrm{kyr}$ BP. These relatively high $\delta^{15} \mathrm{~N}$ values most likely reflect increased nutrient utilization in the Southern Ocean, which resulted in high- $\delta{ }^{15} \mathrm{~N}$ water being advected to the Patagonian fjords, although local denitrification caused by the delivery of copious terrestrial materials and organic matter to the ocean cannot be ruled out. By $\sim 8$ kyr BP continental influences and surface stratification were reduced and characteristic Holocene conditions were established, with increased influence of Southern Ocean water in the western Strait of Magellan. Sea surface temperatures showed millennial-scale changes during the deglaciation and early Holocene, with relatively warm temperatures $\left(11-12{ }^{\circ} \mathrm{C}\right)$ corresponding to the Antarctic counterpart of the Younger Dryas cooling event of the Northern Hemisphere. The longer term pattern $(\sim 10 \mathrm{kyr}$ time scale) in alkenone-derived sea surface temperatures generally follows orbital changes in insolation during austral spring, suggesting a controlling influence of austral spring insolation on southern Patagonian climate.
\end{abstract}

(C) 2013 Elsevier B.V. All rights reserved.

\section{Introduction}

Southern Patagonia is ideally situated for monitoring changes in ocean-atmosphere circulation and ocean-land interactions. Here, the predominant southern westerly winds (SWW), precipitation and freshwater discharge, glacier coverage, tidal currents, and the complex fjord bathymetry control the mixing of freshwater from the continent with water from the sub-Antarctic Pacific Ocean (Porter et al., 1984; Antezana, 1999; Kilian et al., 2007a). The strong seasonal climatic and oceanographic changes affect phytoplankton biomass and species composition (Saggiomo et al., 1994; Iriarte et al., 2001, 2007).

\footnotetext{
* Corresponding author. Tel.: +81 46867 9504; fax: +81 468679455.

E-mail address: haradan@jamstec.go.jp (N. Harada).
}

The present-day core of the SWW is centered at $\sim 50^{\circ} \mathrm{S}$, but there is evidence of past seasonal and millennial-scale changes in its location (Schneider et al., 2003; Lamy et al., 2010). As variations in the strength of the SWW directly affect precipitation regimes, these changes may also affect the mass balance of local glaciers (Schneider et al., 2003). The most recent glacial fluctuation in Patagonia caused variations in the sediment supply and may have acted as an on/off switch for Antarctic dust deposition (Sugden et al., 2009). Therefore, environmental changes in southern Patagonia reflect the driving forces of both local environmental/ecological changes and global climate change.

Several glaciological and palynological investigations have traced the evolution of terrestrial environments in southern Patagonia since the last deglaciation (e.g., McCulloch et al., 2000; Rabassa et al., 2000; McCulloch and Davies, 2001; Sugden et al., 2005; Candel et al., 2009; Douglass et al., 2009; Sugden et al., 2009). There are competing 
hypotheses regarding the pattern and timing of millennial-scale global climate changes in southernmost Patagonia (McCulloch and Davies, 2001; Kilian et al., 2007b; Kaplan et al., 2008) in relation to the marine record in the eastern South Pacific at $41^{\circ} \mathrm{S}$ (Lamy et al., 2004). Sugden et al. (2005) reported that millennial-scale glacial advances and retreats in Patagonia during the last deglaciation were synchronous with cold and warm climate changes, respectively, recorded in the Vostok Antarctic ice core. However, paleoecological studies and ice core records encompassing the Younger Dryas (YD) period, from 12.8 to $11.5 \mathrm{kyr}$ BP (Muscheler et al., 2008), have not found specific evidence that southernmost Patagonia warmed in synchrony with Antarctica and counter to the Northern Hemisphere cooling (Sugden et al., 2005, and references therein), although evidence of such "Antarctic" timing was reported in the high-resolution sea surface temperature (SST) record of Ocean Drilling Program (ODP) Site 1233 at $41^{\circ} \mathrm{S}$ off Chile (Lamy et al., 2004; Kaiser et al., 2005).

Despite indications of terrestrial conditions at high southern latitudes during the most recent deglaciation to Holocene (e.g. Kilian and Lamy, 2012), Holocene oceanographic environmental data are scarce. Thus, our knowledge of oceanographic evolution (water column and biogenic properties) around southernmost Patagonia is incomplete. Here we use a sediment record from the Pacific entrance of the Strait of Magellan (Fig. 1) to provide new constraints on regional marine environmental changes in southernmost Patagonia during the deglacial to Holocene period (13-2.5 kyr BP) in order to better understand the region's sensitivity to climate and sea-level changes. We employ a multi-proxy approach to depict changes in contents and mass accumulation rates (MARs) of total organic carbon (TOC), total nitrogen (TN), total $\mathrm{C}_{37}$ alkenone, and biogenic opal ( $\mathrm{Si}_{\mathrm{OPAL}}$ ). In addition, we use planktic foraminifer assemblages to understand water-mass characteristics (salinity, nutrient conditions, and productivity), $\delta^{13} \mathrm{C}_{\mathrm{TOC}}$ as a proxy for sources of organic matter, and SST estimates derived from alkenones. We also provide a new sedimentary $\delta{ }^{15} \mathrm{~N}$ record for unraveling changes in the nitrogen cycle in southern Patagonia. Our new data help constrain water-mass interactions between the Pacific Ocean and the Strait of Magellan and associated changes in biogenic components, and the $\delta^{15} \mathrm{~N}$ record in particular advances our understanding of regional oceanographic changes during the last deglaciation and the Holocene.

\section{Study site}

The study site is located at the Pacific entrance of the Strait of Magellan $\left(\sim 53^{\circ} \mathrm{S}, 74^{\circ} \mathrm{W}\right)$ (Fig. 1$)$. Here, modern surface circulation is dominated by the Cape Horn Current, a coastal branch of the Antarctic Circumpolar Current (Antezana, 1999) that flows along the southernmost Chilean continental margin toward the Drake Passage and transports sub-Antarctic surface water (Strub et al., 1998). Active exchange of water masses between the Pacific and the western Strait of Magellan is somewhat restricted by the shallow sill (30-40 m depth) near Cape Pilar (Antezana, 1999).

Water-column characteristics at the study site, shown in Fig. 2, were observed by a conductivity-temperature-depth profiler and in water samples taken on 3 March 2009 (late austral summer) during cruise MR08-06 of the R/V Mirai. The upper $\sim 50 \mathrm{~m}$ of the water column was characterized by relatively high temperature $\left(10.5-11.0^{\circ} \mathrm{C}\right)$, low salinity ( $30 \mathrm{psu}$ ), low concentrations of nutrients (nitrate + nitrite, phosphate, and silicic acid), and high levels of dissolved oxygen. Within an apparent halocline at $50-100 \mathrm{~m}$, salinity, nitrate + nitrite, phosphate, ammonium, and oxygen contents changed drastically. Below $100 \mathrm{~m}$ depth, temperature gradually decreased and nutrients increased with depth, and the ammonium concentration was lower than the detection limit. Dissolved oxygen, however, remained near or above $250 \mu \mathrm{mol} \mathrm{kg} \mathrm{kg}^{-1}$ throughout the water column, and oxic conditions extended to the sea bottom at $560 \mathrm{~m}$; the minimum value $\left(\sim 245 \mu \mathrm{mol} \mathrm{kg}{ }^{-1}\right)$ was found at 100-200 m. Because these observations were made during the late summer (active melting season of the coastal glaciers), meltwater may have influenced the upper $\sim 50 \mathrm{~m}$ of the water column, and the $50-100 \mathrm{~m}$ depth interval was presumably occupied by a mixed layer of meltwater and seawater from the Pacific surface and subsurface. The water column characteristics below $\sim 50 \mathrm{~m}$ are indicative of the inflow of a water mass from the Pacific, consistent with circulation studies that have demonstrated the inflow of Pacific water into the Strait of Magellan below $75 \mathrm{~m}$ depth (e.g. Valdenegro and Silva, 2003).

The climate in the Strait of Magellan region is characterized by permanent dominance of the SWW and a strong west-to-east precipitation gradient resulting from the rain shadow of the Andes cordillera (annual precipitation drops from $\sim 7000 \mathrm{~mm}$ at sea level on the (a) Surface temperature $\left({ }^{\circ} \mathrm{C}\right)$

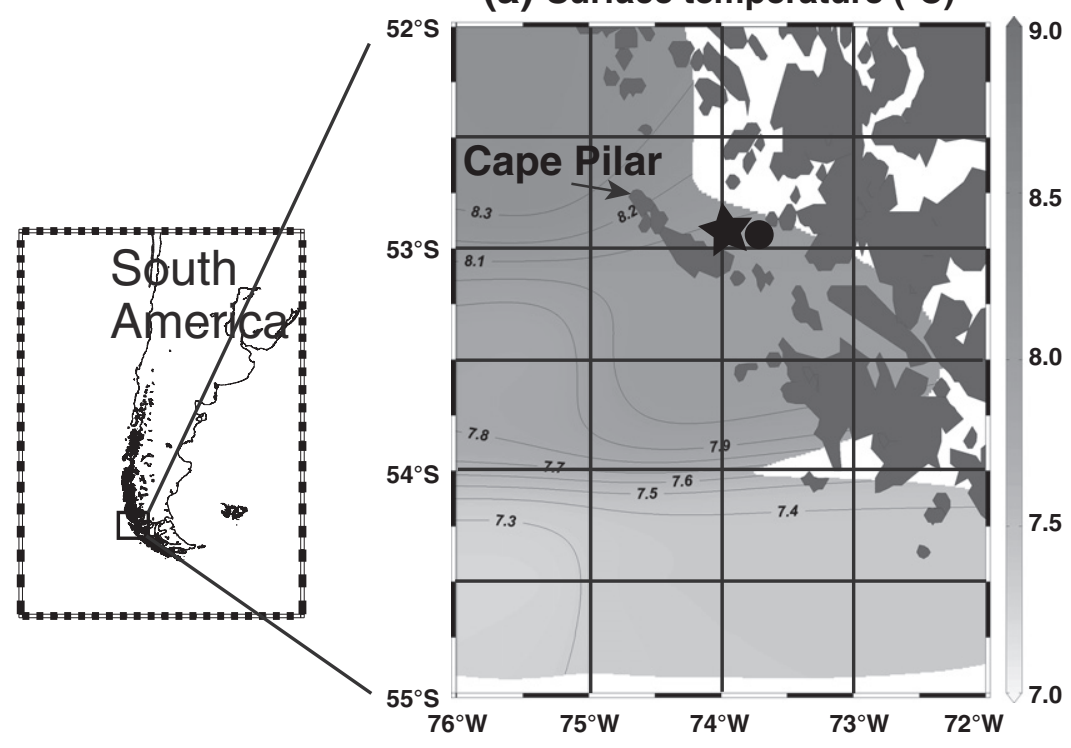

(b) Nitrate $\left(\mu \mathrm{mol} \mathrm{L}^{-1}\right)$

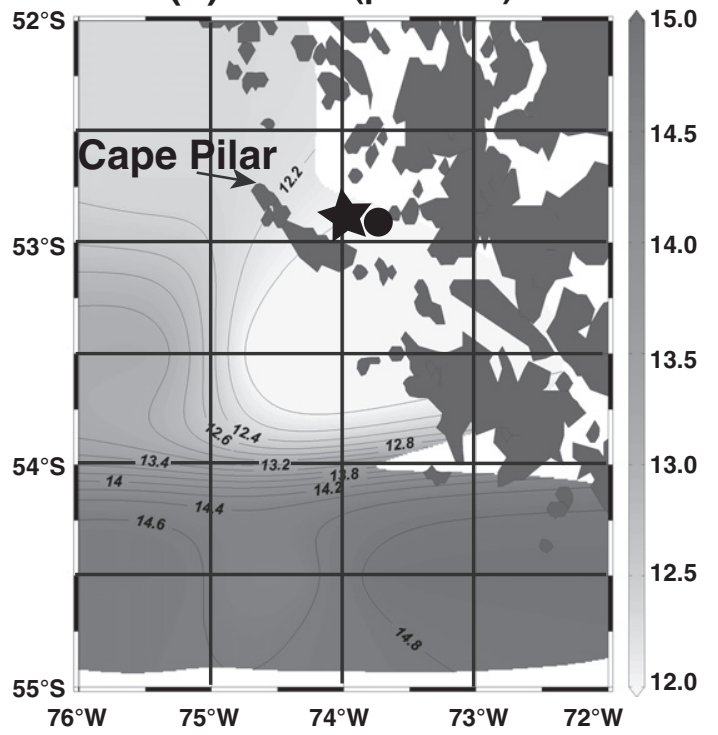

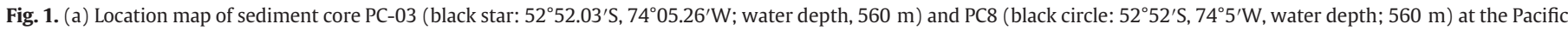

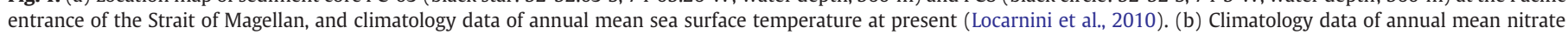
distribution in surface waters at present (Garcia et al., 2010). 


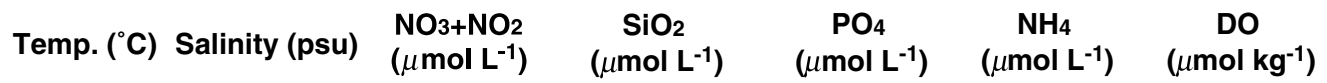

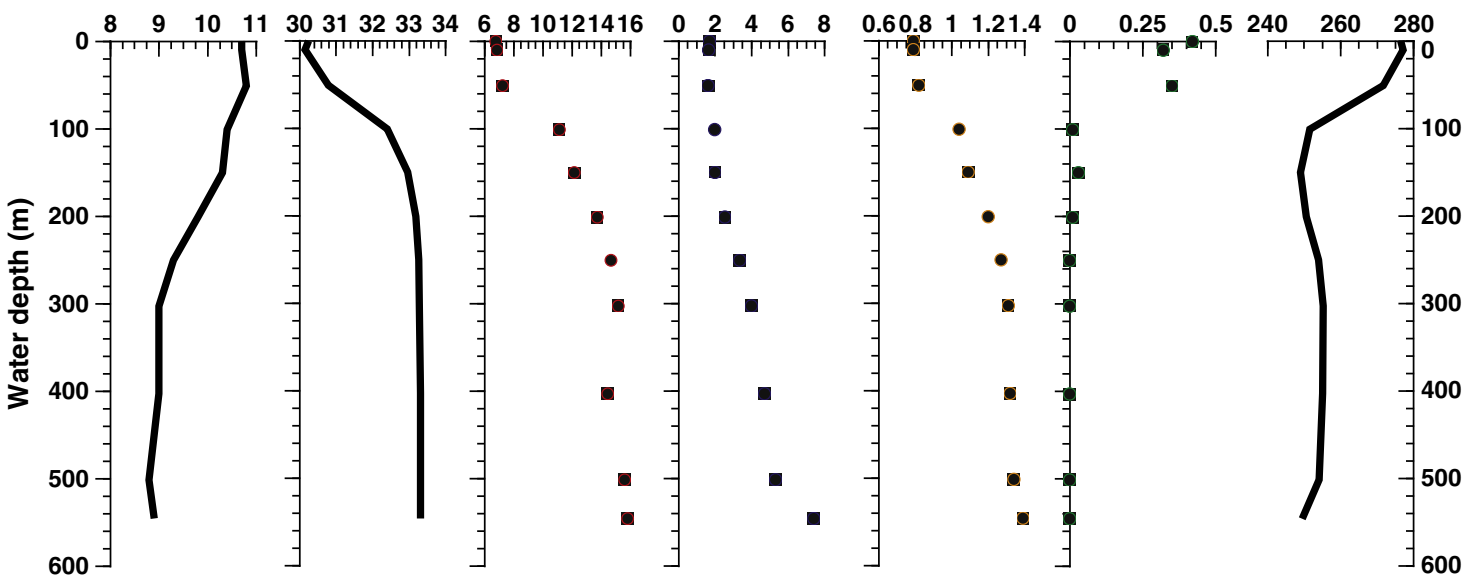

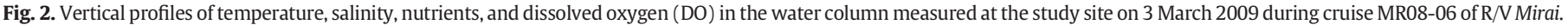

windward side of the Strait of Magellan to $<500 \mathrm{~mm}$ at Punta Arenas; Schneider et al., 2003). At present, the SWW are intensified over southernmost Chile and precipitation is highest, correlating with the stronger SWW, during the austral summer (Schneider et al., 2003). Montade et al. (2011) have shown that distributional changes in the local vegetation of Chilean Patagonia are recorded directly in pollen transported by fluvial input to the surrounding marine sediments, and they suggest that terrestrial environmental changes over time may also be clearly recorded in the marine environment. In addition, pollen inputs from lands east of the Strait of Magellan (Montade et al., 2011) show that easterly winds also exert some influence at these latitudes.

According to Kilian et al. (2007a), at the end of the most recent glacial period, the western section of the Strait of Magellan opened between 14.5 and $13.5 \mathrm{kyr} \mathrm{BP}$, as indicated by a rapid increase in the biogenic carbonate content and the first occurrence of foraminifers in sediment cores collected from the Gran Campo Nevado and Seno Skyring area near the strait. After $\sim 11.5 \mathrm{kyr}$ BP and throughout the Holocene, sedimentation in the western fjords of this region became predominantly autochthonous as a result of higher salinity, clay flocculation, and glacial retreat.

\section{Materials and methods}

Sediment core PC-03 (964 cm in length) was collected from the western Strait of Magellan ( $52^{\circ} 52^{\prime} \mathrm{S}, 74^{\circ} 05^{\prime} \mathrm{W}$; water depth, $560 \mathrm{~m}$ ), about $45 \mathrm{~km}$ southeast of Cape Pilar (Fig. 1). Its sediments consist of calcareous sandy mud containing abundant calcareous fossils. Specimens of the planktic foraminifer Globigerina bulloides were picked from the core for ${ }^{14} \mathrm{C}$ age estimation. The ${ }^{14} \mathrm{C}$ ages were converted to calendar ages (Table 1) using CalPal-2007 software (Weninger et al., 2009). Relatively old reservoir ages have been reported from southernmost Patagonia (e.g. 630 years in the Beagle Channel: Albero et al., 1987). Here we assumed a reservoir age of 680 years, estimated from mollusks collected at Puerto Natales, Chile $\left(51^{\circ} 42^{\prime} \mathrm{S}\right.$, $72^{\circ} 39^{\prime} \mathrm{W}$; Ingram and Southon, 1996). Because there were not enough foraminifers to obtain a ${ }^{14} \mathrm{C}$ age at the core top, the youngest ${ }^{14} \mathrm{C}$ age was determined at $20.5 \mathrm{~cm}$ depth in the core.

Sediment samples were taken at 2.4-cm intervals. Powdered subsamples of $20-30 \mathrm{mg}$ were used to determine TOC (after treatment with $\mathrm{HCl}$ to remove $\mathrm{CaCO}_{3}$ ) and $\mathrm{TN}$ (without $\mathrm{HCl}$ treatment) contents with an elemental analyzer (model 2400II, PerkinElmer Japan Co. Ltd.). Stable isotope ratios of carbon and nitrogen of TOC and TN, respectively, were measured with an elemental analyzer (EA1112, Thermo Fisher Scientific K.K.) interfaced (Conflo III, Thermo Fisher Scientific K.K.) with a mass spectrometer (Delta Plus, Thermo Fisher Scientific K.K.). The analytical error was $<3 \%$ for TOC content of duplicate samples and $<5 \%$ for TN content of duplicates. Carbon and nitrogen isotopic ratios are reported using delta notation. For nitrogen, $\delta^{15} \mathrm{~N}(\%)=\left[\left({ }^{15} \mathrm{~N} /{ }^{14} \mathrm{~N}\right)\right.$ sample $/$ $\left.\left({ }^{15} \mathrm{~N} /{ }^{14} \mathrm{~N}\right)_{\text {standard }}-1\right] \times 1000$, with $\mathrm{N}_{2}$ in air and International Atomic Energy Agency (IAEA) N1 used as reference standards. For carbon, $\delta^{13} \mathrm{C}_{\mathrm{TOC}}(\%)=\left[\left({ }^{13} \mathrm{C} /{ }^{12} \mathrm{C}\right)_{\text {sample }} /\left({ }^{13} \mathrm{C} /{ }^{12} \mathrm{C}\right)_{\text {standard }}-1\right] \times 1000$, with NBS-19 used as the primary standard; values are reported on the VPDB scale. The analytical error was $\pm 0.05 \%$ for $\delta^{13} \mathrm{C}$ and $\pm 0.25 \%$ or for $\delta^{15} \mathrm{~N}$.

Samples for biogenic opal ( $\mathrm{Si}_{\text {OPAL }}$ ) were collected at $10-\mathrm{cm}$ intervals. $\mathrm{Si}_{\mathrm{OPAL}}$ content was determined in freeze-dried sediment samples (25-200 mg) after sequential leaching by the method of Mortlock and Froelich (1989) modified by Müller and Schneider (1993); this method consists of a single extraction of silica in an alkaline solution at $85{ }^{\circ} \mathrm{C}$ for $6 \mathrm{~h}$ and measurement of the dissolved silicon concentration in the extract by molybdate-blue spectrophotometry at $812 \mathrm{~nm}$. The results reported here are expressed as $\operatorname{Si}_{\mathrm{OPAL}}(\%)=112.4 \times(\mathrm{Cs} / \mathrm{M})$, where $\mathrm{Cs}=$ silica concentration in the sample (nM), $\mathrm{M}=$ sample mass $(\mathrm{mg})$, and $112.4=$ atomic weight of $\mathrm{Si}(28.09) \times$ the extraction volume of $\mathrm{NaOH}(0.04 \mathrm{~L}) \times 100$.

For alkenones, bulk organic compounds were extracted from 1 to $3 \mathrm{~g}$ of freeze-dried sediments (sampled at $\sim 10-\mathrm{cm}$ intervals) with an accelerated solvent extractor (ASE-200, DIONEX Japan Ltd.). The extracts were then saponified and the neutral fraction was separated by silica gel column chromatography by using an automatic solidpreparation system (Rapid Trace SPE Workstation, Zymark Ctr.), as described by Harada et al. (2003). Each alkenone fraction was analyzed by capillary gas chromatography (Agilent Technologies, Inc.).

Table 1

Age model of core PC-03 at $53^{\circ} \mathrm{S}$. Accelerator mass spectrometry ${ }^{14} \mathrm{C}$ dates and conversion to calendar ages, based on the planktic foraminifer Globigerina bulloides, and linear sedimentation rates.

\begin{tabular}{llrllll}
\hline & $\begin{array}{l}\text { Depth in } \\
\text { core } \\
(\mathrm{cm})\end{array}$ & ${ }^{14} \mathrm{C}$ age & $\begin{array}{l}{ }^{14} \mathrm{C} \text { age } \\
\text { error }^{\mathrm{a}} \\
(\mathrm{yr} \mathrm{BP})\end{array}$ & $\begin{array}{l}\text { Calendar } \\
\text { age } \\
(\mathrm{yr} \mathrm{BP})\end{array}$ & $\begin{array}{l}\text { Calendar } \\
\text { age error }(1 \sigma) \\
(\mathrm{yr})\end{array}$ & $\begin{array}{l}\text { Sedimentation } \\
\text { rate } \\
\left(\mathrm{cm} \mathrm{kyr}^{-1}\right)\end{array}$ \\
\hline & 21.4 & 2750 & 50 & 2577 & 57 & - \\
2 & 96.2 & 4300 & 50 & 4618 & 52 & 35.9 \\
3 & 145.7 & 5240 & 40 & 5747 & 76 & 40.9 \\
4 & 207.2 & 6920 & 40 & 7475 & 46 & 36.1 \\
5 & 302.7 & 8320 & 50 & 9066 & 68 & 58.7 \\
6 & 403 & 8890 & 50 & 9750 & 104 & 143.4 \\
7 & 602.2 & 9810 & 60 & 10,953 & 34 & 161.9 \\
8 & 804.7 & 10,420 & 60 & 12,068 & 179 & 177.6 \\
\hline
\end{tabular}

a Error is the range of the estimates. 
The analytical error for alkenone concentration estimated from replicate analyses was $5 \%$. The alkenone unsaturation index $U_{37}^{K^{\prime}}$, the ratio of methyl alkenones with 37 carbon atoms and two double bonds to those with two and three double bonds $\left(\mathrm{U}_{37}^{\mathrm{K}^{\prime}}=\left[\mathrm{C}_{37: 2}\right] /\right.$ $\left.\left[C_{37: 2}+C_{37: 3}\right]\right)$, was used for calculating SST. In this study, we used the calibration equation $\mathrm{U}_{37}^{\mathrm{K}^{\prime}}=0.034 \mathrm{~T}\left({ }^{\circ} \mathrm{C}\right)+0.039$ (Prahl et al., 1988). Some of the samples were measured in duplicate $(n=5)$, and the temperatures estimated from replicate analyses differed by $\pm 0.5{ }^{\circ} \mathrm{C}(1 \sigma)$. Although tetra-unsaturated $C_{37}$ alkenone $\left(C_{37: 4}\right)$ was present in the samples (relative abundance $<10 \%$ ), we did not incorporate it into the SST estimates, as $\mathrm{C}_{37: 4}$ may respond to environmental variables (i.e. salinity) other than temperature (Sikes and Sicre, 2002).

Biogenic proxies $\mathrm{TOC}, \mathrm{TN}, \mathrm{Si}_{\mathrm{OPAL}}$, and alkenone are also reported in terms of their MARs. Conversion from concentration to mass was performed by multiplying the contents of each proxy by dry bulk density and the sedimentation rate.

The sediment samples (collected at 4-cm or 6-cm intervals) for planktic foraminiferal assemblages were divided into three fractions ( $>212,150-212$, and $63-150 \mu \mathrm{m}$ fractions) by sieving them through three sieves, dried in an oven at $50{ }^{\circ} \mathrm{C}$, and then stored in vials. Assemblages were determined by using an Olympus stereomicroscope. Foraminiferal assemblage analysis was based on the $>150-\mu \mathrm{m}$ fraction after counting $>200$ individuals per sample.

\section{Results and discussion}

\subsection{Age model and sedimentation rates}

We based the age model of core PC-03 on eight ${ }^{14} \mathrm{C}$ accelerator mass spectrometry dates and linear interpolation between the age control points (Table 1 and Fig. 3). According to our age model, core PC-03 covers the time interval from 2.5 to approximately $13 \mathrm{kyr}$ BP. We did not include data from the core top $(0-20.9 \mathrm{~cm})$, which was disturbed by piston coring. Estimated sedimentation rates were $143-178 \mathrm{~cm} \mathrm{kyr}^{-1}$ in the late deglacial period and early Holocene, decreasing to very low values (36-59 $\mathrm{cm} \mathrm{kyr}^{-1}$ ) after 9 kyr BP (Table 1 and Fig. 3).

The piston corer could not penetrate deeper than $10 \mathrm{~m}$ into the sediment even though two attempts were made at the same position with a $20-\mathrm{m}$ stainless tube and a 1.25-ton weight. It seems likely that the sediment matrix changed from marine sand (relatively coarse and soft) to glacial clay (very fine and hard) at around $10 \mathrm{~m}$ depth. The age obtained at the bottom of core PC-03 was $\sim 13 \mathrm{kyr}$ BP, which approximately corresponds to the period of the main marine transgression in the western Strait of Magellan ( 14.5-13.5 kyr BP; Kilian et al., 2007a).

\subsection{Changes in local sea level and their influence on biogenic components}

TOC content in core PC-03 varied between $0.35 \%$ and $1.58 \%$ (Fig. 3). It was low during the late deglaciation and the early Holocene until $8.5 \mathrm{kyr}$ BP ( 0.5\%), and then increased rapidly, reaching $1 \%$ at about $8 \mathrm{kyr}$ BP. Thereafter, TOC content increased gradually to the top of the core. TN content ranged from $0.04 \%$ to $0.2 \%$ (Fig. 3 ) and showed a similar pattern of change to that of TOC. We found relatively low $\delta^{13} C_{\text {TOC }}$ values of $-24 \%$ at the bottom of the core that gradually increased to $-22 \%$ after $11.5 \mathrm{kyr} \mathrm{BP}$, and values of $-20 \%$ o were observed after $\sim 6 \mathrm{kyr}$ BP (Fig. 3). The $\delta^{13} \mathrm{C}_{\text {TOC }}$ record suggests a mixture of terrestrial and marine sources of organic carbon during the deglacial-early Holocene period, whereas autochthonous material (of phytoplankton origin) became the main contributor to the export flux thereafter. The total content of $C_{37}$ alkenones $\left(C_{37: 2}, C_{37: 3}\right.$, and $C_{37: 4}$ ) ranged from 0.13 to $0.84 \mu \mathrm{g}$ per gram dry weight of sediment $\left(\mu \mathrm{g} \mathrm{g}^{-1}\right)$ (Fig. 3). When normalized by TOC content, $C_{37}$ alkenone values ranged from 21.1 to $70.1 \mu \mathrm{g}$ per gram dry weight of TOC. In both cases, values were low during the late deglaciation and rapidly increased between 8.5 and $8 \mathrm{kyr} \mathrm{BP}$, reaching two maxima during the middle Holocene, at 7-8 and 5.2 kyr BP. The overall contribution of $\mathrm{C}_{37: 4}$ to the $\mathrm{C}_{37}$ alkenone content $\left(\% \mathrm{C}_{37: 4}\right)$ was low but changed radically with time; it ranged from $6 \%$ to $8.5 \%$ in the late deglaciation and early Holocene and was $2 \%$ after 8 kyr BP (Fig. 3).

A remarkable feature of the biogenic components is the strong and abrupt increase in TOC, TN, and total $\mathrm{C}_{37}$ alkenone contents in the early Holocene at $\sim 9-8 \mathrm{kyr} \mathrm{BP}$, coinciding with the drop in $\% \mathrm{C}_{37: 4}$ and also with an abrupt decrease in the sedimentation rate, which evidently controlled the accumulation rate or influenced the concentration of the biogenic components. These signals at 9-8 kyr BP might reflect enhancement of open marine influence in the Strait of Magellan after the quasi-termination of the postglacial sea-level rise. Although $\% \mathrm{C}_{37: 4}$ is difficult to use as a proxy for global salinity (Sikes and Sicre, 2002), it has been shown to be inversely correlated with regional salinity changes at high latitudes in the North Atlantic (e.g. Bendle et al., 2005) and North Pacific (Harada et al., 2003). The decrease in $\% \mathrm{C}_{37: 4}$ in core $\mathrm{PC}-03$ from higher values during the late deglaciation to very low values after 8 kyr BP suggests an evolution from relatively low regional salinity during the late deglaciation through a gradual change between 10 and $8 \mathrm{kyr}$ BP to the establishment of a more oceanic salinity at $8 \mathrm{kyr}$ BP. The timing of these changes in our core ( 9-8 kyr BP) coincides with changes observed elsewhere; in core MD07-3132 (53 $44^{\prime} \mathrm{S}, 70^{\circ} 19^{\prime} \mathrm{W}, 301 \mathrm{~m}$ water depth), similar changes in alkenones, a strong increase in biogenic carbonate accumulation rates, and an increase in pore water chlorinity suggestive of higher salinities in both bottom and surface waters were observed (Aracena, 2011; Kilian and Lamy, 2012). At around 9-8 kyr BP, sea level was 20-40 m lower than at present and just rising over the sill near Cape Pilar; thus, Pacific Ocean water, which probably started to intrude vigorously into the Strait of Magellan at $~ 9 \mathrm{kyr}$ $\mathrm{BP}$, can account for the sudden changes in TOC, TN, and alkenone contents and $\% \mathrm{C}_{37: 4}$. The incursion of Pacific water would primarily affect the subsurface given the nature of fjord circulation (Valdenegro and Silva, 2003), and a change in the planktic foraminiferal $\delta^{18} \mathrm{O}$ could be expected. However, the $\delta^{18} \mathrm{O}$ of Neogloboquadrina pachyderma and Globigerina bulloides did not show a large change at $\sim 9 \mathrm{kyr}$ BP (U. Ninnemann, unpublished data), although the relative abundance of $N$. pachyderma seems to have increased at the time (Fig. 4).

Another possibility is that glacial melting and/or precipitation fluxes into the Strait of Magellan decreased rapidly after $\sim 9$ kyr BP. The sedimentary record of $\mathrm{Al}_{2} \mathrm{O}_{3}$, which originates from terrestrial material, collected near PC-03 at PC8 $\left(52^{\circ} 52^{\prime} \mathrm{S}, 74^{\circ} 5^{\prime} \mathrm{W}\right)$ showed that the $\mathrm{Al}_{2} \mathrm{O}_{3}$ flux dramatically decreased after $\sim 9$ kyr BP, a finding that implies that rapid melting of the Patagonian ice sheet ended at about that time (Shiroya et al., in press). Regarding the precipitation-related record, Lamy et al. (2010) and Kilian and Lamy (2012) studied marine and continental records from fjord systems near the Pacific entrance to the Strait of Magellan and described wetter and windier conditions west of the Andes from 12.5 to $~ 8.5 \mathrm{kyr}$ BP, a transitional period in the middle Holocene, and dominantly drier conditions from $\sim 5.2 \mathrm{kyr}$ BP to the present. A drop in the rate of glacial melting or in precipitation fluxes might have changed the degree of surface stratification and freshening, thus affecting surface-oriented proxies (e.g. TOC and alkenones), but not subsurface foraminiferal habitats.

Other lines of evidence support an enhancement of the marine influence in the Strait of Magellan at $\sim 9 \mathrm{kyr}$ BP. At this time TOC, TN, $\mathrm{Si}_{\mathrm{OPAL}}$, and alkenone MARs changed abruptly, from 0.40 to $1.9 \mathrm{~g} \mathrm{~cm}^{-2} \mathrm{kyr}^{-1}, 0.05$ to $0.24 \mathrm{~g} \mathrm{~cm}^{-2} \mathrm{kyr}^{-1}, 0.41$ to $6.4 \mathrm{~g} \mathrm{~cm}^{-2} \mathrm{kyr}^{-1}$, and 15 to $81 \mu \mathrm{g} \mathrm{cm}^{-2} \mathrm{kyr}^{-1}$, respectively (Fig. 5). The pattern of change followed that of the sedimentation rate (which was highest in the late deglacial-early Holocene and lowest after 9 kyr BP; Fig. 3), suggesting that the accumulation of biogenic components at the study site is mainly controlled by the sedimentation rate. Fukuda et al. (in press) used ${ }^{230}$ Th activity at our study site to document enhanced sediment focusing ${ }^{1}$ during the late deglacial-

\footnotetext{
${ }^{1}$ A process whereby water turbulence and currents transport settling material.
} 


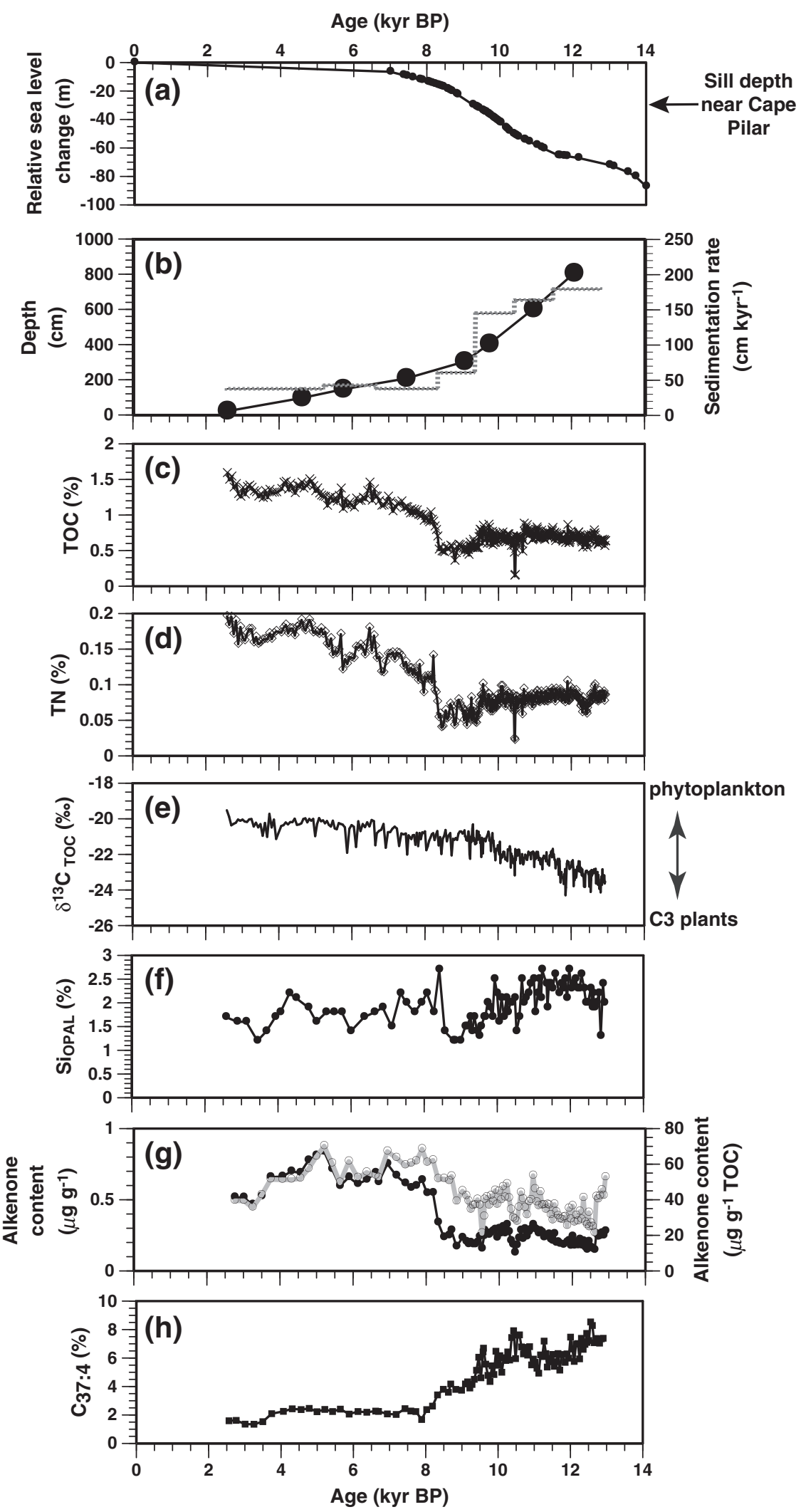

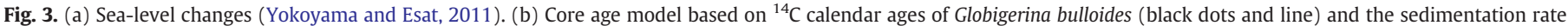

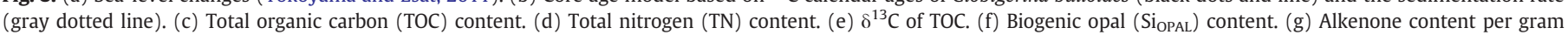
dry weight of sediment (black dots and line) and per gram of TOC (open circles and gray line). (h) Percent contribution of $\mathrm{C}_{37: 4}$ to the total alkenone amount.

early Holocene, which was followed by a reduction in focusing after $\sim 8 \mathrm{kyr} \mathrm{BP}$. The terrestrial material and $\mathrm{Al}_{2} \mathrm{O}_{3}$ fluxes at the PC8 also changed dramatically, from $2000-4000 \mathrm{~g} \mathrm{~cm}^{-2} \mathrm{kyr}^{-1}$ at 9-12 $\mathrm{kyr}$
BP to $500 \mathrm{~g} \mathrm{~cm}^{-2} \mathrm{kyr}^{-1}$ after $~ 9 \mathrm{kyr}$ BP; this timing also corresponds to changes in the sedimentation rate (Shiroya et al., in press). The large salinity changes suggested by the changes in 

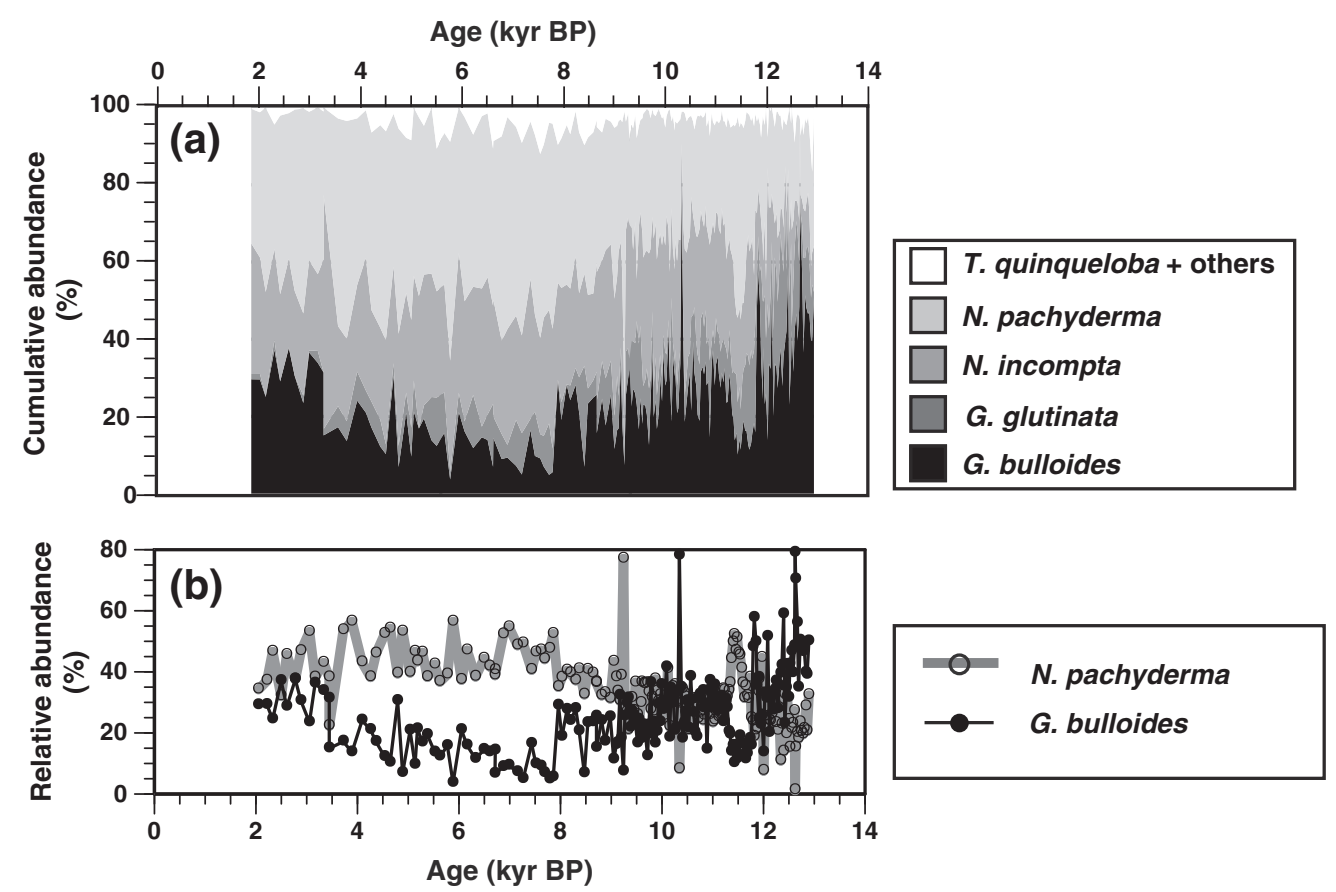

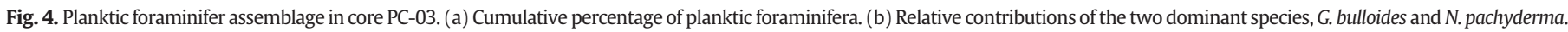

$\% \mathrm{C}_{37: 4}$ PC-03 indicate that the transport of glacial detritus might have dominantly influenced the sediment supply during the late deglacial-early Holocene. It seems likely that the changes in the MARs of biogenic components reflect the control of sediment input by the dilution effect of glacier melting events and the terrestrial material supply. This interpretation is consistent with the rapid reduction of freshwater influence in the Strait of Magellan area after $\sim 9$ kyr BP suggested by the $\mathrm{Al}_{2} \mathrm{O}_{3}$ fluxes (Shiroya et al., in press).

4.3. Changes in productivity from $\mathrm{Si}_{O P A L}$ and water-mass characteristics from planktic foraminiferal assemblages

In contrast to the trend detected in $\mathrm{TOC}, \mathrm{TN}$, and total $\mathrm{C}_{37}$ alkenones, $\mathrm{Si}_{\text {OPAL }}$ content was relatively high during the deglaciation $(\sim 2.5 \%$, 12.5-10.5 kyr BP), then decreased to a minimum at ca. 9 kyr BP and remained lower at around $1-2 \%$ (except for a peak of $2.7 \%$ at $8.3 \mathrm{kyr}$ BP) throughout the Holocene (Fig. 3). Because $\mathrm{Si}_{\text {OPAL }}$ in sediments of the Chilean Patagonia fjords region strongly correlates with primary production in the water column (Aracena et al., 2011), our time series of $\mathrm{Si}_{\mathrm{OPAL}}$ content in core $\mathrm{PC}-03$ may reflect water-column productivity at the study site. However, the relatively high values of $\mathrm{Si}_{\text {OPAL }}$ may also be related to an additional supply of freshwater siliceous microfossils (i.e. freshwater diatoms, Chrysophycean cysts) during the wetter deglacial-early Holocene period, as has been observed in a nearby site in the Churruca fjord $\left(53^{\circ} 02^{\prime} \mathrm{S}, 73^{\circ} 56^{\prime} \mathrm{W}\right)$, in the western section of the Strait of Magellan (S. Sandoval unpublished data). The production of biogenic silica in the Southern Ocean is controlled by the silicon nutrient supply, which is promoted by upwelling of circumpolar deep water (Trull et al., 2001). After upwelling, Si and other nutrients are transported equatorward by Antarctic Intermediate Water and sub-Antarctic Mode Water. During 17-10 kyr BP, wind-driven upwelling in the Southern Ocean was stronger than during the Holocene, and biogenic opal production increased along the Polar Front at this time (Anderson et al., 2009). Thus, the higher $\mathrm{Si}_{\text {OPAL }}$ content during 12.5-10.5 kyr BP at our study site may reflect mixed sources, namely, both nutrient advection from the Polar Front and increased delivery of freshwater diatoms. It is worth noting that during the last deglaciation, when $\mathrm{Si}_{\mathrm{OPAL}}$ values were high, indicating enhanced nutrient advection and/or freshwater diatom production, alkenone production was not high (Fig. 3). Discrepancies between the $\mathrm{Si}_{\mathrm{OPAL}}$ and total $\mathrm{C}_{37}$ alkenone time series through the deglacial-Holocene have also been found in the North Pacific and its marginal seas (Minoshima et al., 2007; Harada et al., 2008). Such discrepancies might reflect differences in
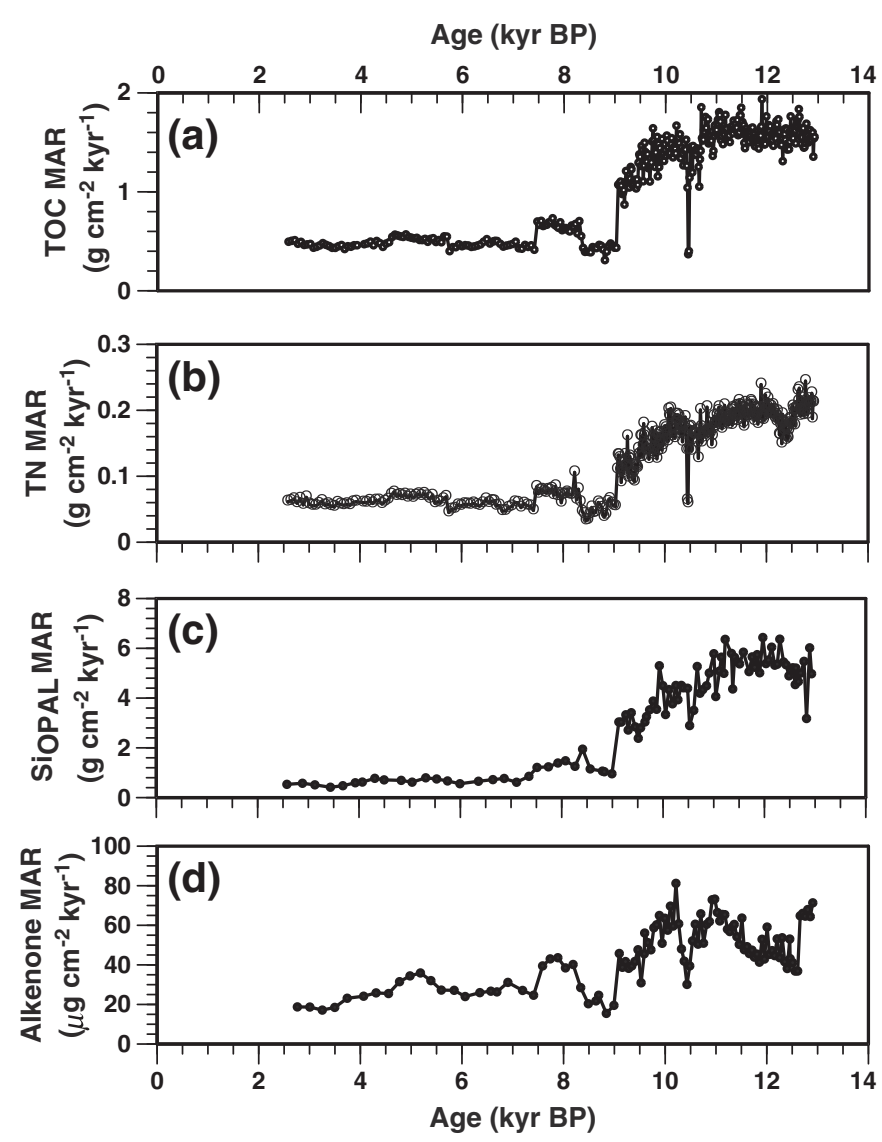

Fig. 5. Mass accumulation rates (MARs) of (a) TOC, (b) TN, (c) Si OPAL, and (d) alkenones. 
the nutrient preferences of diatoms and alkenone producers (Harada et al., 2006).

The planktic foraminifers Globigerina bulloides, Globorotalia inflata, Neogloboquadrina incompta, Neogloboquadrina pachyderma, Globorotalia crassaformis, Orbulina universa, Globigerinita glutinata, and Turborotalia quinqueloba were present within the past $13 \mathrm{kyr}$ in core PC-03. The diversity of planktic foraminifers was relatively low, with the three dominant species (G. bulloides, N. pachyderma and N. incompta) accounting for $56-99 \%$ of the total foraminifer abundance (Fig. 4a). The proportion of $G$. bulloides in the assemblage was greater (20-60\%) during the deglaciation (with a short reduction at $\sim 11.5 \mathrm{kyr}$ BP) than during the Holocene (Fig. 4b): At $\sim 8 \mathrm{kyr}$ BP, its abundance dropped abruptly from $\sim 30 \%$ to $<10 \%$, after which it gradually increased to near $40 \%$ by $3.5 \mathrm{kyr}$ BP. In contrast, the proportion of $N$. pachyderma was smaller during the deglaciation $(<40 \%)$ than subsequently, and it increased gradually throughout the Holocene, aside from a distinct spike at 9-9.5 kyr BP (Fig. 4b). The contribution of $N$. incompta to foraminifer abundance was lower and more stable than that of $N$. pachyderma. The abundance trends of $G$. bulloides and N. pachyderma were mirror images of one another even though both taxa generally prefer cold-water conditions (Hemleben et al., 1988). In the Atlantic sector of the Southern Ocean $\left(41-53^{\circ} \mathrm{S}, 5-12^{\circ} \mathrm{E}\right)$, G. bulloides is dominant in the central sub-Antarctic, whereas $N$. pachyderma is dominant at more southerly sites (Mortyn and Charles, 2003). In addition, the occurrence of $G$. bulloides is associated with the fluorescence peak in deep parts of the surface mixed layer and is tied to phytoplankton blooms. Peak abundances of $N$. pachyderma have been observed in the chlorophyll-maximum zone in the Northeast Water Polynya within the East Greenland Current (Kohfeld et al., 1996) and in the western North Pacific (Kuroyanagi and Kawahata, 2004). These distributions suggest that both G. bulloides and N. pachyderma are closely associated with a phytoplankton food source that is controlled by the density structure of the water column. To the south of the modern Polar Front in the Atlantic sector of the Southern Ocean, most abundance peaks of $N$. pachyderma are shallower than the fluorescence peak below the pycnocline (Mortyn and Charles, 2003), implying that its distribution is influenced by non-biological, local hydrographic effects such as eddy mixing and advection (Ortiz et al., 1995; Kohfeld et al., 1996; Mortyn and Charles, 2003). In addition, N. pachyderma has strict minimum salinity requirements (e.g. Hilbrecht, 1996; Hillaire-Marcel et al., 2004).

The complementary pattern of abundances between Globigerina bulloides and Neogloboquadrina pachyderma through 13-2.5 kyr at our study site probably reflects changes in mixing and stratification conditions of surface waters and a difference in the relative contributions of water masses: A greater abundance of $G$. bulloides may indicate the dominance of a shallower (stratified), sub-Antarctic water mass, whereas a greater abundance of $N$. pachyderma suggests the dominance of a deeper water mass originating further south in the Southern Ocean. During 13-9 kyr BP, glacial meltwater and precipitation may have strengthened water-column stratification, creating the preferred environment of $G$. bulloides. Thereafter, during the middle and late Holocene, the influence of Southern Ocean water, preferred by $N$. pachyderma, increased. This interpretation is consistent with the observed time-series changes in the organic matter supply between terrestrial and marine origins (Fig. 3) and the movement of the SWW core (and its associated precipitation); during the early Holocene the SWW mainly influenced southern Patagonia, but in the mid to late Holocene, its influence was extended northward (Lamy et al., 2010).

\subsection{Changes in the nitrogen cycle}

In high-latitude regions, where surface water is rich in dissolved oxygen and nutrients, $\delta^{15} \mathrm{~N}$ of bulk sediment mainly reflects changes in nitrate consumption, if other processes influencing $\delta^{15} \mathrm{~N}$ values of bulk sediment (e.g. terrestrial input) are constant (Altabet and François, 1994). The mean $\delta^{15} \mathrm{~N}$ value of nitrate in subsurface ocean waters is usually about $5 \%$. We found high $\delta^{15} \mathrm{~N}$ in the range $9-11 \%$ at $53^{\circ} \mathrm{S}$ during $13-10 \mathrm{kyr}$ BP (Fig. 6), suggesting that nitrate consumption was prominent at these high latitudes. In addition, $\delta^{15} \mathrm{~N}$ values at our study site were somewhat lower than those further north (at $41^{\circ} \mathrm{S}$ ) at ODP Site 1233 , where $\delta^{15} \mathrm{~N}$ values were also relatively high during 13-10 kyr BP (Fig. 6); this result is consistent with the $\delta^{15} \mathrm{~N}$ pattern in surface sediments between $20^{\circ} \mathrm{S}$ and $45^{\circ} \mathrm{S}$ off Chile (De Pol-Holz et al., 2009). Martinez et al. (2006) suggested that the nitrogen isotopic variations off Chile are controlled mostly by hydrologic and climatic changes in the Southern Ocean. They inferred, therefore, that the ODP Site 1233 record resulted from an interplay between nutrient demand in the sub-Antarctic zone and latitudinal shifts of hydrologic fronts that controlled the concentration and isotopic signature of the nitrate delivered to the Chile margin.

One possible source of the high $\delta^{15} \mathrm{~N}$ values in the high-latitude eastern South Pacific during the late deglaciation is the advection of water already affected by denitrification into the Strait of Magellan. Denitrification in the water column is typically accompanied by strong isotopic fractionation due to incomplete bacterial conversion of nitrate to $\mathrm{N}_{2}$, which can result in high $\delta^{15} \mathrm{~N}$ values, ranging from $9 \%$ o to $18 \%$ 。 (Brandes et al., 1998). At present, water-column denitrification occurs only in regions with oxygen minimum zones. Although water-column denitrification off Peru and Chile intensified during 18-10 kyr BP (De Pol-Holz et al., 2006), it is very unlikely that surface and subsurface waters at the study site $\left(\sim 53^{\circ} \mathrm{S}\right)$ were influenced by the advection of a denitrified water mass from lower latitudes, because upwelling at the study site was suppressed by the onshore SWW.

An alternative explanation is that denitrification occurred locally in the water column. The $\delta^{15} \mathrm{~N}$ enrichment during 13-10 kyr BP was concurrent with a high TOC MAR of $\sim 2 \mathrm{~g} \mathrm{~cm}^{-2} \mathrm{kyr}^{-1}$. This value, which is attributable both to sediment focusing (Fukuda et al., in press) and high sedimentation rates, is about five times the Holocene rate of $0.5 \mathrm{~g} \mathrm{~cm}^{-2} \mathrm{kyr}^{-1}$. Such local denitrification might have been a response to a reduced oxygen concentration caused by remineralization of large amounts of organic material. The western coast and Andean regions of Patagonia are permanently under the influence of the SWW, and the SWW core has undergone repeated northward and southward migrations (e.g. Mohtadi and Hebbeln, 2004; Moreno, 2004). These migrations control the latitudinal position of the macronutrient-rich Antarctic Circumpolar Current (Garcia et al., 2010), and precipitation runoff is also an important source of nutrients and terrestrial material to coastal waters of western South America. As mentioned in Section $4.2, \delta^{13} \mathrm{C}_{\mathrm{TOC}}$ during $13-11 \mathrm{kyr}$ BP ranged from $-24 \%$ o to $-23 \%$ o (Fig. 3), suggesting that an increased supply of terrestrial material contributed to a high export flux of organic materials and may have led locally to water-column oxygen consumption and associated local denitrification. Local denitrification associated with the relatively low $\delta^{13} C_{\text {TOC }}$ values, then, might be evidence that the SWW core intensified over southernmost Patagonia during the late deglacial-earliest Holocene, in agreement with the findings of Lamy et al. (2010). This interpretation is also consistent with

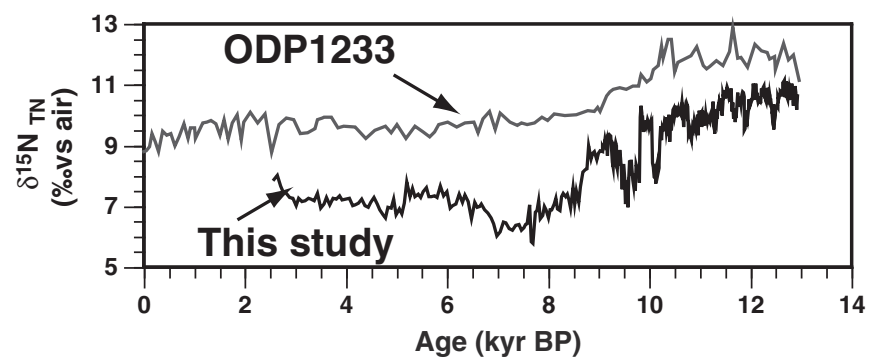

Fig. 6. Changes in $\delta^{15} \mathrm{~N}$ of total nitrogen relative to atmospheric $\mathrm{N}_{2}$ compared to the record from ODP Site 1233 (Martinez et al., 2006). 
the relatively high abundance of Globigerina bulloides and low abundance of Neogloboquadrina pachyderma (Fig. 4). It cannot explain, however, why the $\delta^{15} \mathrm{~N}$ trend is the same as that at ODP Site 1233 at $41^{\circ} \mathrm{S}$ (Fig. 6) as well as at sites much further north.

Another possible explanation for the ${ }^{15} \mathrm{~N}$ enrichment during 13-10 kyr BP is a change in relative nutrient utilization in precursor waters of the surface and subsurface water masses at the study site. Biological production was relatively high in the Southern Ocean during 13-10 kyr BP (Anderson et al., 2009), and this high production in the Southern Ocean might have increased relative nutrient utilization, thus increasing the $\delta^{15} \mathrm{~N}$ signal without requiring any changes in local water-column denitrification. This increase in the $\delta^{15} \mathrm{~N}$ signal would be reflected in the $\delta^{15} \mathrm{~N}$ value of waters entering the Patagonian fjords and could explain the higher $\delta{ }^{15} \mathrm{~N}$ values observed at sites influenced by the Antarctic Circumpolar Current (Fig. 6).

\subsection{Changes in SST indicated by the alkenone record}

Alkenone-derived SST oscillated between a minimum of $8.7^{\circ} \mathrm{C}$ at $3.3 \mathrm{kyr}$ BP and a maximum of $12.1^{\circ} \mathrm{C}$ at $8.3 \mathrm{kyr}$ BP (Fig. 7). The late deglacial-early Holocene SST record is characterized by a warming interval during 13-11 kyr BP, coincident with the YD cooling event in the Northern Hemisphere. The warming trend of the late deglacialearly Holocene is also recorded in the alkenone SST from the continental slope west of the Strait of Magellan at $53^{\circ} \mathrm{S}$ (Caniupán et al., 2011). Other evidence of warm SSTs approximately corresponding to the YD interval has been found in sediments from the continental margin off Chile at $33^{\circ} \mathrm{S}$ (Kim et al., 2002), at $35^{\circ} \mathrm{S}$ (Romero et al., 2006), and at $30^{\circ} \mathrm{S}$ (Kaiser et al., 2008). The retreat of the Patagonian Ice Sheet (Heusser, 2003; McCulloch et al., 2005) is consistent with regional warming during the YD. According to McCulloch et al. (2005), glacial retreat in the central Strait of Magellan (12.6-11.8 kyr BP) occurred during the coolest part of the YD in the Northern Hemisphere. The palynological record from Lago Guanaco in Torres del Paine $\left(50^{\circ} \mathrm{S}\right)$ shows a rapid increase in Nothofagus at $\sim 12.3 \mathrm{kyr}$ BP, suggesting colonization of newly deglaciated terrain by forests (Moreno et al., 2009). Within the YD interval, SSTs at our study site ranged from $10.1{ }^{\circ} \mathrm{C}$ to $11.7^{\circ} \mathrm{C}$, and a short and abrupt cooling (with SSTs below $9.6{ }^{\circ} \mathrm{C}$ ) took place at $\sim 12.6$ kyr BP.

Our record from the Pacific entrance of the Strait of Magellan shows warming in the early Holocene, reaching a climate optimum from 10 to $~ 6 \mathrm{kyr}$ BP (Fig. 7) similar in timing to the Holocene Climate Optimum, observed during $11-8 \mathrm{kyr}$ BP at a site close to our site $\left(53^{\circ} \mathrm{S}\right.$, Caniupán et al., 2011) and during 11-9 kyr BP further north (Kaiser et al., 2005). Warming in the early Holocene is a widespread feature at mid-latitudes in the eastern South Pacific (Kaiser et al., 2005, 2008), and proxy records from the Antarctic Peninsula also demonstrate significant warming during 11-9 kyr BP (Bentley et al., 2009). This warm period was interrupted at our study site by a short cool event centered at $10.5 \mathrm{kyr} \mathrm{BP}$, when alkenone-SSTs decreased from $11.8^{\circ} \mathrm{C}$ to $9.8^{\circ} \mathrm{C}$. The timing of this event is similar to that of a major Holocene glacial advance at 9.7-9.3 $\mathrm{kyr}$ BP, reported at the San Rafael Glacier $\left(46^{\circ} 40^{\prime} \mathrm{S}\right.$, $73^{\circ} 55^{\prime} \mathrm{W}$; Harrison et al., 2012). This cool event also approximately coincides with a sudden drop at $10 \mathrm{kyr}$ BP in pollen of hygrophytes from a peat bog at $53^{\circ} \mathrm{S}$ (Lamy et al., 2010). After $6 \mathrm{kyr}$ BP, alkenone-SSTs decreased steadily, similar to the trend at $41^{\circ} \mathrm{S}$ (Fig. 7) and at $30^{\circ} \mathrm{S}$ (Kaiser et al., 2008), although the decline was much greater at $53^{\circ} \mathrm{S}$ than at the more northern sites.

In sediment cores GIK17748-2 and GeoB 3302-1 from $33^{\circ} \mathrm{S}$ off Chile, variation in the $\mathrm{Fe} / \mathrm{Al}$ ratio (interpreted as a proxy for rainfall and the position of the SWW) indicates that the SWW migrated northward and southward on millennial timescales during the deglaciation (Lamy et al., 2000). This migration may play a role in highand mid-latitude SST changes Chilean marginal region since the Last

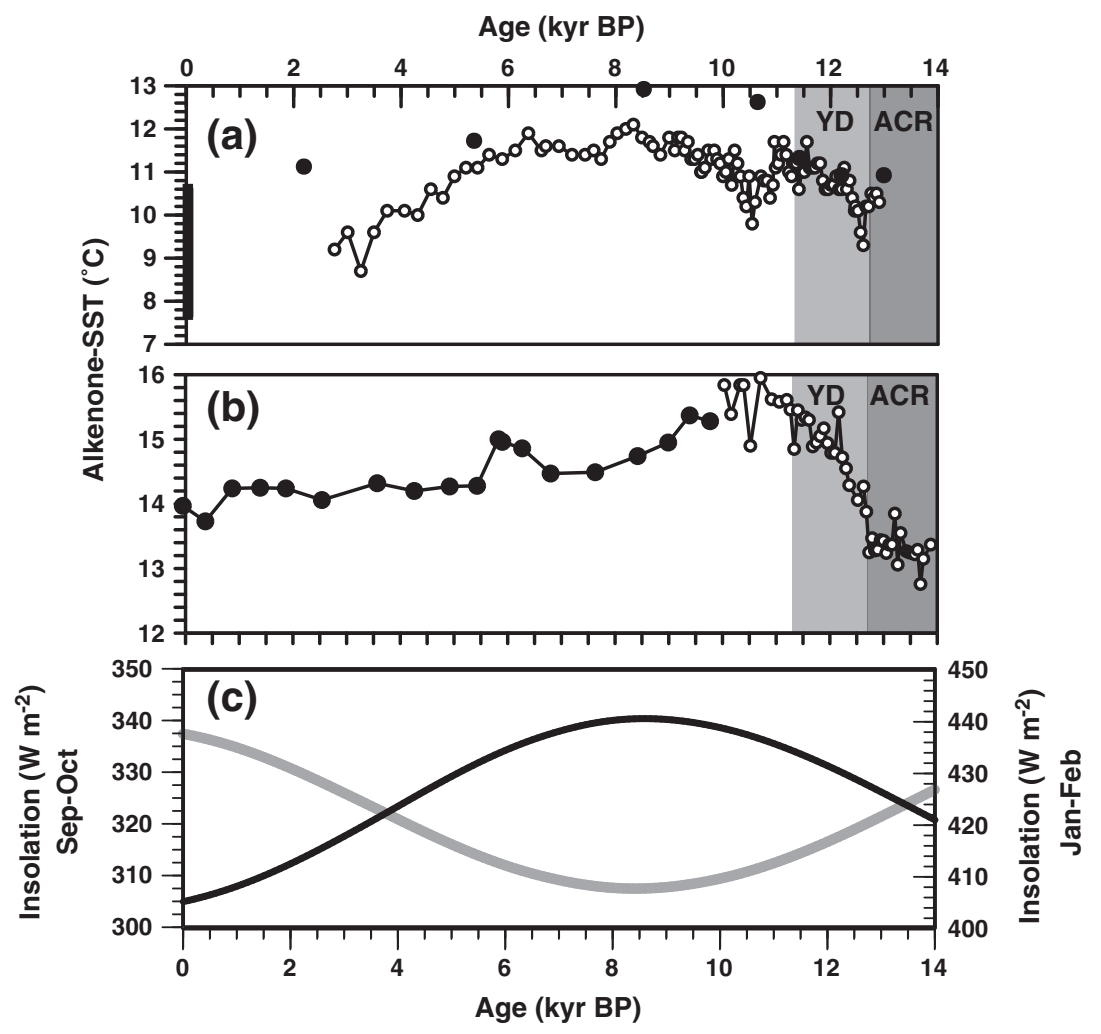

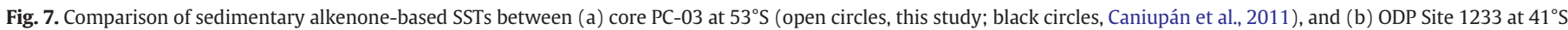

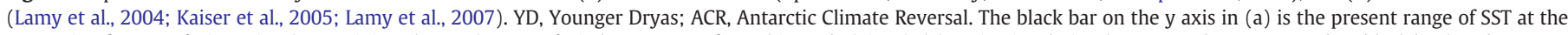

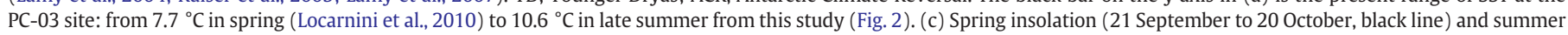
insolation (21 January to 20 February, gray line) at $53^{\circ} \mathrm{S}$, from Laskar et al. (2004). 
Glacial Maximum. The alkenone-SST changes that we observed at $53^{\circ} \mathrm{S}$ during the late deglaciation follow a similar pattern to the alkenone-SST record off Chiloé at ODP Site $1233\left(41^{\circ} \mathrm{S}\right)$, which is in the pelagic zone at the northern margin of the SWW belt (Lamy et al., 2004; Kaiser et al., 2005; Lamy et al., 2007). Although the overall pattern is similar at these two sites, there are differences. For example, the magnitude of the deglacial warming (after the Antarctic Cold Reversal) at $53^{\circ} \mathrm{S}$ was $\sim 1.5^{\circ} \mathrm{C}$, which is smaller than the $\sim 2{ }^{\circ} \mathrm{C}$ recorded at ODP Site 1233. Likewise, the warming trend from $\sim 10$ to $\sim 6 \mathrm{kyr}$ BP observed at $53^{\circ} \mathrm{S}$ was not apparent at ODP Site 1233. While both ODP Site 1233 at $41^{\circ} \mathrm{S}$ and our study site would have been influenced by both tropical and polar atmospheric and oceanographic circulation mechanisms, the differences between them may be due to ODP Site 1233 being particularly sensitive to tropical Pacific forcing mechanisms (Lamy et al., 2004), whereas our study site might be more sensitive to polar forcing mechanisms.

Although the alkenone-SSTs near the PC-03 core top $\left(\sim 9-10{ }^{\circ} \mathrm{C}\right)$ at 3-3.5 kyr BP (Fig. 7) apparently correspond to present-day monthly average temperatures at $10 \mathrm{~m}$ depth for January-March, the alkenone-SSTs at the core top of multiple cores collected close to our study site were $8-9{ }^{\circ} \mathrm{C}$, temperatures that correspond to the annual mean SST or to late spring or early fall SSTs (Locarnini et al., 2010). When the long-term pattern of alkenone-SST changes $(\sim 10 \mathrm{kyr}$ scale) in the western Strait of Magellan is compared with insolation, the SST trends seem to follow the insolation trend in austral spring (September-October) at $53^{\circ} \mathrm{S}$ (Fig. 7; Laskar et al., 2004), as opposed to austral summer, consistent with the notion that spring orbital forcing is a key pacemaker for deglacial and interglacial climate changes in the Southern Hemisphere (Stott et al., 2007; Timmermann et al., 2009). For example, Timmermann et al. (2009) suggested that increasing austral spring insolation forcing between 20 and $10 \mathrm{kyr}$ BP caused a reduction in the Southern Ocean sea ice area and increased absorption of shortwave radiation, leading to warming and further sea ice reduction in the Southern Ocean.

\section{Summary}

Using multiple proxies from a core obtained near the Pacific entrance of the Strait of Magellan, we investigated the deglacial-Holocene (13-2.5 kyr BP) changes in productivity, water-mass characteristics, and the nitrogen cycle in response to local climate and sea-level changes, and also changes in SST associated with the SWW and insolation factors (Fig. 8).

From 13 to $11 \mathrm{kyr}$ BP, corresponding to the Northern Hemisphere YD cold event, SSTs increased in a pattern similar to that observed further north in Chilean margin sediments. The long-term pattern of alkenone-SSTs corresponds to insolation during the austral spring (September-October). During 13-9 kyr BP, TOC, TN, and total $C_{37}$ alkenone contents were all elevated relative to levels after 9 kyr BP. Likewise, the abundance of Globigerina bulloides was relatively high (and that of Neogloboquadrina pachyderma was relatively low) prior to $9 \mathrm{kyr}$ BP, implying that glacial meltwater and precipitation strengthened water-column stratification, favoring $G$. bulloides. The MARs of biogenic components were also high before 9 kyr BP. Moreover, $\delta{ }^{13} \mathrm{C}_{\text {Toc }}$ values ranged from $-24 \%$ o to $-23 \%$, whereas $\delta{ }^{15} \mathrm{~N}$ was high, ranging from $10 \%$ to $11 \%$. Taken together, the organic carbon, nutrient cycling, and hydrographic indicators suggest that an increase in the supply of terrestrial materials contributed to a high organic matter export flux, increasing water-column oxygen consumption and local denitrification during the late deglaciation. Alternatively, increased nutrient utilization by phytoplankton in the Southern Ocean may have led to advection of nutrients with relatively high $\delta^{15} \mathrm{~N}$ into the Patagonian fjords, although lower sea level at the time would have restricted this exchange.

During the Holocene, SSTs peaked at $\sim 8 \mathrm{kyr}$ BP and $\sim 6.4 \mathrm{kyr}$ BP (early and mid-Holocene optima, respectively). Thereafter, SSTs declined steadily until about $3.5 \mathrm{kyr}$ BP. The coherence of SST evolution near the core of the SWW belt $\left(53^{\circ} \mathrm{S}\right)$ with that near its northern limits (at $41^{\circ} \mathrm{S}$ ) suggests a gradual equatorward shift of the SWW axis during the Holocene, driving gradual cooling at both locations. At 9-8 kyr BP, the sedimentation rate and $\% \mathrm{C}_{37: 4}$ abruptly decreased, probably reflecting the enhancement of open marine influence in the western Strait of Magellan after the quasi-termination of the postglacial sea-level rise. Alternatively, they may reflect a substantial change in the sedimentary environment, or a reduction of local precipitation or meltwater runoff. At the same time, the increased abundance of Neogloboquadrina pachyderma documents an increased influence of Southern Ocean waters. As a result of pronounced advection of Southern Ocean water, the TOC, TN, and total $\mathrm{C}_{37}$ alkenone contents became comparatively high, suggesting increased productivity at the Pacific entrance of the Strait of Magellan at about 9-8 kyr BP.

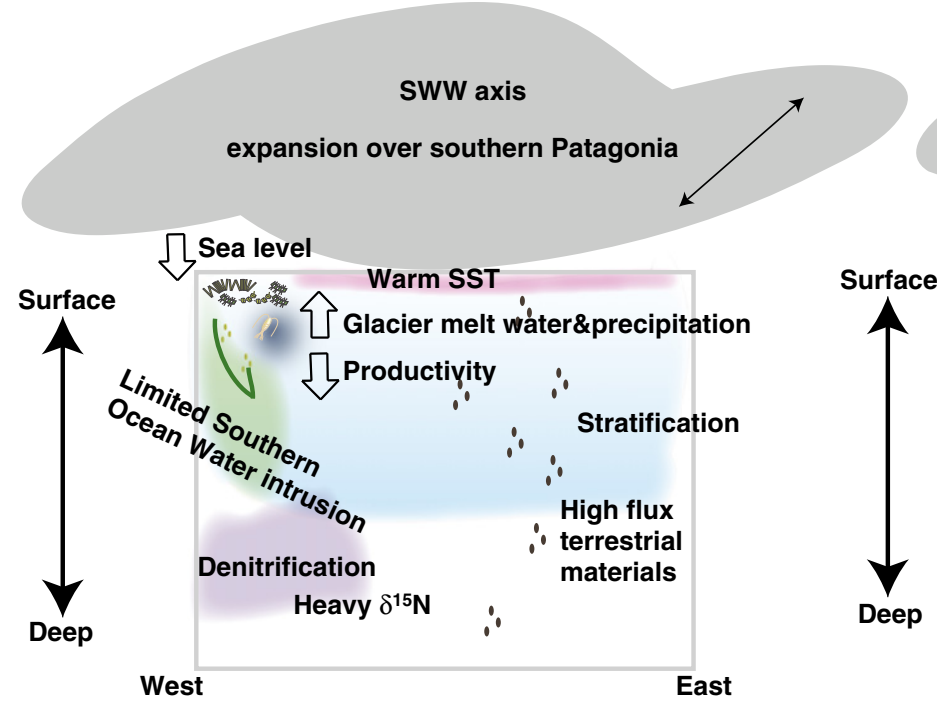

(a) 13-9 kyr BP

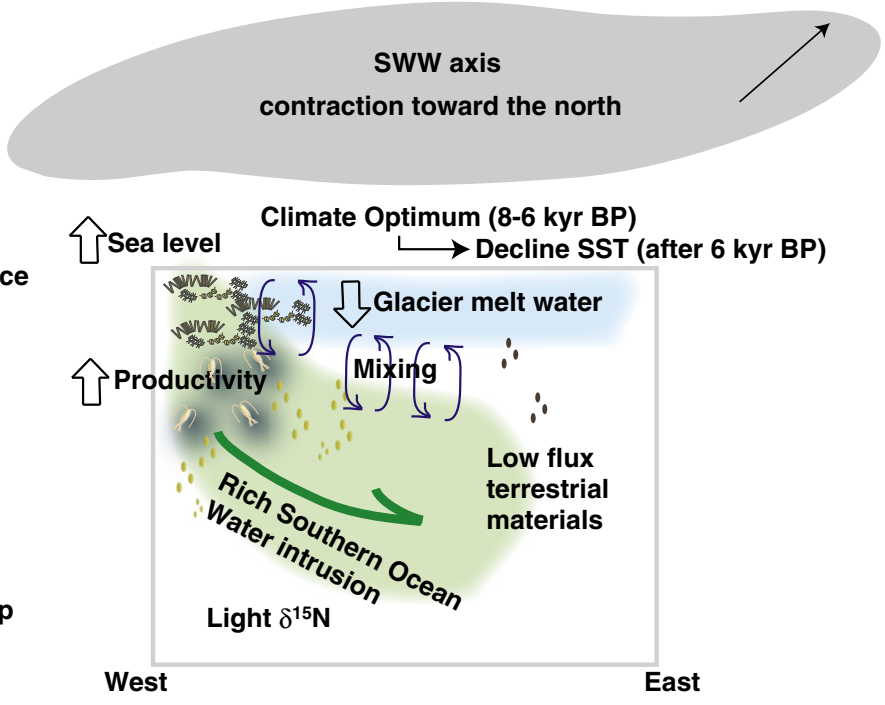

(b) 9-2.5 kyr BP

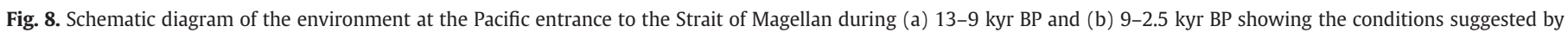
various proxies. 


\section{Acknowledgments}

We are grateful to Captain Akamine and the crew of R/V Mirai for their help with sediment collection and water-column sampling during cruise MR08-06. We thank F. Lamy for providing comments on an earlier version of this manuscript. This paper benefited from important comments by Thierry Corrège, Associate Editor and an anonymous reviewer. This work was supported by the Japan Agency for Marine-Earth Science and Technology, and in part by the Center for Oceanographic Research in the Eastern South Pacific (COPAS Center CONICYT grant no. 150100007).

\section{References}

Albero, M.C., Angiolini, F., Piana, L., 1987. Holocene ${ }^{14}$ C reservoir effect at Beagle Channel (Tierra del Fuego, Argentina Republic). In: Rabassa, J. (Ed.), Quaternary of South America and Antarctic Peninsula, vol. 5. Balkema Publishers, Rotterdam, pp. 59-71.

Altabet, M.A., François, R., 1994. Sedimentary nitrogen isotopic ratio as a recorder for surface nitrate utilization. Global Biogeochemical Cycles 8, 103-116.

Anderson, R.F., Ali, S., Bradtmiller, L.I., Nielsen, S.H.H., Fleisher, M.Q., Anderson, B.E., Burckle, L.H., 2009. Wind-driven upwelling in the Southern Ocean and the deglacial rise in atmospheric $\mathrm{CO}_{2}$. Science 323, 1443-1448.

Antezana, T., 1999. Hydrographic features of Magellan and Fuegian inland passages and adjacent subantarctic waters. Scientia Marina 63, 23-34.

Aracena, C., 2011. Fluctuaciones de la paleoproductividad en la cuenca del Estrecho de Magallanes, su relación con la transgresión marina y los cambios climáticos en Patagonia Sur. PhD thesis, University of Concepción, Chile, 234 pp.

Aracena, C., Lange, C.B., Iriarte, J.L., Rebolledo, L., Pantoja, S., 2011. Latitudinal patterns of export production recorded in surface sediments of the Chilean Patagonian fjords $\left(41-55^{\circ} \mathrm{S}\right)$ as a response to water column productivity. Continental Shelf Research 31, 340-355.

Bendle, J., Rosell-Melé, A., Ziveri, P., 2005. Interannual variability and paleoceanographic implications of unusual distributions of alkenones in the surface waters of the Nordic Seas. Paleoceanography 20, PA2001. http://dx.doi.org/10.1029/2004PA001025.

Bentley, M.J., Hodgson, D.A., Smith, J.A., Cofaigh, C.Ó., Domack, E.W., Larter, R.D., Roberts, S.J., Brachfeld, S., Leventer, A., Hjort, C., Hillenbrand, C.-D., Evans, J., 2009. Mechanisms of Holocene palaeoenvironmental change in the Antarctic Peninsula region. The Holocene 19, 51-69.

Brandes, J.A., Devol, A.H., Yoshinari, T., Jayakumar, D.A., Naqvi, S.W.A., 1998. Isotopic composition of nitrate in the central Arabian Sea and eastern tropical North Pacific: a tracer for mixing and nitrogen cycles. Limnology and Oceanography 43, 1680-1689.

Candel, M.S., Borromei, A.M., Martínez, M.A., Gordillo, S., Quattrocchio, M., Rabassa, J., 2009. Middle-Late Holocene palynology and marine mollusks from Archipelago Cormoranes area, Beagle Channel, southern Tierra del Fuego, Argentina. Palaeogeography, Palaeoclimatology, Palaeoecology 273, 111-122.

Caniupán, A.M., Lamy, F., Lange, C.B., Kaiser, J., Arz, H.W., Kilian, R., Baeza Urrea, O., Aracena, C., Hebbeln, D., Kissel, C., Laj, C., Mollenhauer, G., Tiedemann, R., 2011. Millennial-scale sea surface temperature and Patagonian Ice Sheet changes off southernmost Chile $\left(53^{\circ} \mathrm{S}\right)$ over the past $60 \mathrm{kyr}$. Paleoceanography 26, PA3221. http://dx.doi.org/10.1029/2010PA002049.

De Pol-Holz, R., Ulloa, O., Dezileau, L., Kaiser, J., Lamy, F., Hebbeln, D., 2006. Melting of the Patagonian Ice Sheet and deglacial perturbations of the nitrogen cycle in the eastern South Pacific. Geophysical Research Letters 33, L04704. http://dx.doi.org/ 10.1029/2005GL024477.

De Pol-Holz, R., Robinson, R.S., Hebbeln, D., Sigman, D.M., Ulloa, O., 2009. Controls on sedimentary nitrogen isotopes along the Chile margin. Deep-Sea Research Part II $56,1042-1054$.

Douglass, D.C., Singer, B.S., Kaplan, M.R., Ackert, R.P., Mickelson, D.M., Caffee, M.W., 2009. Evidence of early Holocene glacial advances in southern South America from cosmogenic surface-exposure dating. Geology 33, 237-240.

Fukuda, M., Harada, N., Sato, M., Lange, C.B., Ahagon, N., Kawakami, H., Miyashita, W., Pantoja, S., Matsumoto, T., Motoyama I., in press. ${ }^{230}$ Th-normalized fluxes of biogenic components from the central and southernmost Chilean margin over the past 22,000 years. Geochemical Journal.

Garcia, H.E., Locarnini, R.A., Boyer, T.P., Antonov, J.I., Zweng, M.M., Baranova, O.K., Johnson, D.R., 2010. World Ocean Atlas 2009, volume 4: nutrients (phosphate, nitrate, silicate). In: Levitus, S. (Ed.), NOAA Atlas NESDIS 71. U.S. Government Printing Office, Washington, D.C., p. 398.

Harada, N., Shin, K.-H., Murata, A., Uchida, M., Nakatani, T., 2003. Characteristics of alkenones synthesized by a bloom of Emiliania huxleyi in the Bering Sea. Geochimica et Cosmochimica Acta 67, 1507-1519.

Harada, N., Sato, M., Shiraishi, A., Honda, M.C., 2006. Characteristics of alkenone distributions in suspended and sinking particles in the northwestern North Pacific. Geochimica et Cosmochimica Acta 70, 2045-2062.

Harada, N., Sato, M., Sakamoto, T., 2008. Freshwater impacts recorded in tetraunsaturated alkenones and alkenone sea surface temperatures from the Okhotsk Sea across millennial-scale cycles. Paleoceanography 23, PA3201. http://dx.doi.org/10.1029/ 2006PA001410.

Harrison, S., Glasser, N.F., Duller, G.A.T., Jansson, K.N., 2012. Early and mid-Holocene age for the Tempanos moraines, Laguna San Rafael, Patagonian Chile. Quaternary Science Reviews 31, 82-92. http://dx.doi.org/10.1016/j.quascirev. 2011.10.15.
Hemleben, C.H., Spindler, M., Anderson, O.R., 1988. Modern Planktonic Foraminifera. Springer-Verlag. New York Inc.(363 pp.).

Heusser, C.J., 2003. Ice Age Southern Andes: a chronicle of paleoecological events Developments in Quaternary Science, 3. Elsevier, The Netherlands (254 pp.).

Hilbrecht, H., 1996. Extant planktic foraminifera and the physical environment in the Atlantic and Indian Oceans. Mitteilungen aus dem Geologischen Institut der Eidgen. Technischen Hochschule und der Universität Zürich, Neue Folge, No. 300 (93 pp., Zürich).

Hillaire-Marcel, C., de Vernal, A., Polyak, L., Darby, D., 2004. Size-dependent isotopic composition of planktic foraminifers from Chukchi Sea vs. NW Atlantic sedimentsimplications for the Holocene paleoceanography of the western Arctic. Quaternary Science Reviews 23, 245-260.

Ingram, B.L., Southon, J.R., 1996. Reservoir ages in Eastern Pacific coastal and estuarine waters. Radiocarbon 38, 573-582.

Iriarte, J.L., Kusch, A., Osses, J., Ruiz, M., 2001. Phytoplankton biomass in the subAntarctic area of the Straits of Magellan $\left(53^{\circ} \mathrm{S}\right)$, Chile during spring-summer 1997/1998. Polar Biology 24, 154-162.

Iriarte, J.L., González, H.E., Liu, K.K., Rivas, C., Valenzuela, C., 2007. Spatial and temporal variability of chlorophyll and primary productivity in surface waters of southern Chile $\left(41.5-43^{\circ} \mathrm{S}\right)$. Estuarine, Coastal and Shelf Science 74, 471-480.

Kaiser, J., Lamy, F., Hebbeln, D., 2005. A 70-kyr sea surface temperature record off southern Chile (Ocean Drilling Program Site1233). Paleoceanography 20, PA4009. http://dx.doi.org/10.1029/2005PA001146.

Kaiser, J., Schefuß, E., Lamy, F., Mohtadi, M., Hebbeln, D., 2008. Glacial to Holocene changes in sea surface temperature and coastal vegetation in north central Chile: high versus low latitude forcing. Quaternary Science Reviews 27, 2064-2075.

Kaplan, M.R., Fogwill, C.J., Sugden, D.E., Hulton, N.R.J., Kubik, P.W., Freeman, S.P.H.T., 2008. Southern Patagonian glacial chronology for the Last Glacial period and implications for Southern Ocean climate. Quaternary Science Reviews 27, 284-294.

Kilian, R., Lamy, F., 2012. A review of Glacial and Holocene Paleoclimate records from southernmost Patagonia (49-55 $\left.{ }^{\circ} \mathrm{S}\right)$. Quaternary Science Reviews 53, 1-23.

Kilian, R., Beaza, O., Steinke, T., Arevalo, M., Rios, C., Schneider, C., 2007a. Late Pleistocene to Holocene marine transgression and thermohaline control on sediment transport in the western Magellanes fjord system of Chile $\left(53^{\circ} \mathrm{S}\right)$. Quaternary International 161, 90-107.

Kilian, R., Schneider, C., Koch, J., Fesq-Martin, M., Biester, H., Casassa, G., Arévalo, M. Wendt, G., Baeza, O., Behrmann, J., 2007b. Palaeoecological constraints on late Glacial and Holocene ice retreat in the Southern Andes (53 degrees S). Global and Planetary Change 59, 49-66.

Kim, J.-H., Schneider, R.R., Hebbeln, D., Müller, P.J., Wefer, G., 2002. Last deglacial seasurface temperature evolution in the Southeast Pacific compared to climate changes on the South American continent. Quaternary Science Reviews 21, 2085-2097.

Kohfeld, K.E., Fairbanks, R.G., Smith, S.L., Walsh, I.D., 1996. Neogloboquadrina pachyderma (sinistral-coiling) as paleoceanographic tracers in polar oceans: evidence from northeast water polynya plankton tows, sediment traps, and surface sediments. Paleoceanography 11, 679-699.

Kuroyanagi, A., Kawahata, H., 2004. Vertical distribution of living planktonic foraminifera in the seas around Japan. Marine Micropaleontology 53, 173-196.

Lamy, F., Hebbeln, D., Wefer, G., Marchant, M., 2000. Reconstructing latitudinal shifts of the Southern Westerlies from marine sediment studies along the Chilean continental margin. Pages Newsletter 2000-2, 8-9.

Lamy, F., Kaiser, J., Ninnemann, U., Hebbeln, D., Arz, H.W., Stoner, J., 2004. Antarctic timing of surface water changes off Chile and Patagonian ice sheet response. Science 304, 1959-1962.

Lamy, F., Kaiser, J., Arz, H.W., Hebbeln, D., Ninnemann, U., Timm, O., Timmermann, A Toggweiler, J.R., 2007. Modulation of the bipolar seesaw in the South Pacific during Termination 1. Earth and Planetary Science Letters 259, 400-413. http://dx.doi.org/ 10.1016/j.epsl.2007.04.040.

Lamy, F., Kilian, R., Arz, H.W., Francois, J.-P., Kaiser, J., Prange, M., Steinke, T., 2010 Holocene changes in the position and intensity of the Southern Westerly wind belt. Nature Geoscience 3, 695-699.

Laskar, J., Robutel, P., Joutel, F., Gastineau, M., Correia, A.C.M., Levrard, B., 2004. A longterm numerical solution for the insolation quantities of the Earth. Astronomy and Astrophysics 428, 261-285.

Locarnini, R.A., Mishonov, A.V., Antonov, J.I., Boyer, T.P., Garcia, H.E., Baranova, O.K., Zweng M.M., Johnson, D.R., 2010. World Ocean Atlas 2009, volume 1: temperature. In: Levitus, S. (Ed.), NOAA Atlas NESDIS 68. U.S. Government Printing Office, Washington, D.C., p. 184.

Martinez, P., Lamy, F., Robinson, R.R., Pichevin, L., Billy, I., 2006. Atypical $\delta^{15} \mathrm{~N}$ variations at the southern boundary of the East Pacific oxygen minimum zone over the last 50 ka. Quaternary Science Reviews 25, 3017-3028.

McCulloch, R.D., Davies, S.J., 2001. Late-glacial and Holocene paleoenvironmental change in the central Strait of Magellan, southern Patagonia. Palaeogeography, Palaeoclimatology, Palaeoecology 173, 143-173.

McCulloch, R.D., Bentley, M.J., Purves, R.S., Hulton, N.R.J., Sugden, D.E., Clapperton, C.M., 2000. Climatic inferences from glacial and paleoecological evidence at the last glacial termination, southern South America. Journal of Quaternary Science 15 (4), 409-417.

McCulloch, R.D., Fogwill, C.J., Sugden, D.E., Bentley, M.J., Kubik, P.W., 2005. Chronology of the last glaciation in central Strait of Magellan and Bahía Inútil, southernmost South America. Geografiska Annaler 87, 289-312.

Minoshima, K., Kawahata, H., Ikehara, K., 2007. Changes in biological production in the mixed water region (MWR) of the northwestern North Pacific during the last 27 kyr. Palaeogeography, Palaeoclimatology, Palaeoecology 254, 430-447.

Mohtadi, M., Hebbeln, D., 2004. Mechanisms and variations of paleoproductivity off northern Chile $\left(24^{\circ} \mathrm{S}-33^{\circ} \mathrm{S}\right)$ during the last 40,000 years. Paleoceanography 19 , PA 2023. http://dx.doi.org/10.1029/2004PA001003. 
Montade, V., Nebout, N.C., Kissel, C., Mulsow, S., 2011. Pollen distribution in marine surface sediments from Chilean Patagonia. Marine Geology 282, 161-168. http:// dx.doi.org/10.1016/j.margeo.2011.02.001.

Moreno, P.I., 2004. Millennial-scale climate variability in northwest Patagonia over the last 15,000 yr. Journal of Quaternary Science 19, 35-47.

Moreno, P.I., Kaplan, M.R., François, J.P., Villa-Martínez, R., Moy, C.M., Stern, C.R., Kubik, P.W., 2009. Renewed glacial activity during the Antarctic cold reversal and persistence of cold conditions until $11.5 \mathrm{ka}$ in southwestern Patagonia. Geology 37, 375-378.

Mortlock, R.A., Froelich, P.N., 1989. A simple method for the rapid determination of biogenic opal in pelagic marine sediments. Deep-Sea Research Part I 36, 1415-1426.

Mortyn, P.G., Charles, C.D., 2003. Planktonic foraminiferal depth habitat and $\delta^{18} 0$ calibrations: plankton tow results from the Atlantic sector of the Southern Ocean. Paleoceanography 18, 1037. http://dx.doi.org/10.1029/2001PA000637.

Müller, P., Schneider, R., 1993. An automated leaching method for the determination of opal in sediments and particulate matter. Deep Sea Research 40, 425-444.

Muscheler, R., Kromer, B., Björck, S., Svensson, A., Friedrich, M., Kaiser, K.F., Southon, J., 2008. Three rings and ice cores reveal ${ }^{14} \mathrm{C}$ calibration uncertainties during the Younger Dryas. Nature Geoscience 1, 263-267.

Ortiz, J.D., Mix, A.C., Collier, R.W., 1995. Environmental control of living symbiotic and asymbiotic foraminifera of the California Current. Paleoceanography 10, 987-1009.

Porter, S.C., Stuiver, M., Heusser, C.J., 1984. Holocene sea-level changes along the Strait of Magellan and Beagle Channel, southernmost South America. Quaternary Research 22, 59-67.

Prahl, F.G., Muehlhausen, L.A., Zahnle, D.L., 1988. Further evaluation of long-chain alkenones as indicators of paleoceanographic conditions. Geochimica et Cosmochimica Acta 52, 2303-2310.

Rabassa, J., Coronato, A., Bujalesky, G., Salemme, M., Roig, C., Meglioli, A., Heusser, C., Gordillo, S., Roig. F., Borromei, A., Quattrocchio, M., 2000. Quaternary of Tierra del Fuego, Southernmost South America; an updated review. Quaternary International 68-71, 217-240.

Romero, O.E., Kim, J.-H., Hebbeln, D., 2006. Paleoproductivity evolution off central Chile from the Last Glacial Maximum to the Early Holocene. Quaternary Research 65, 519-525.

Saggiomo, V., Goffart, A., Carrada, G.C., Hecq, J.H., 1994. Spatial patterns of phytoplanktonic pigments and primary production in a semi-enclosed periantarctic ecosystem: the Strait of Magellan. Journal of Marine Systems 5, 119-142.
Schneider, C., Glaser, M., Kilian, R., Santana, A., Butorovic, N., Casassa, G., 2003. Weather observations across the Southern Andes at 53 ${ }^{\circ}$ S. Physical Geography 24, 97-119.

Shiroya, K., Yokoyama Y., Obrochta, S., Harada, N., Miyairi Y., Matsuzaki H., in press. Melting history of the Patagonian Ice Sheet during Termination I inferred from marine sediments. Geochemical Journal.

Sikes, E.L., Sicre, M.A., 2002. Relationship of the tetra-unsaturated C37 alkenone to salinity and temperature: implications for paleoproxy applications. Geochemistry, Geophysics, Geosystems 3 (11), 1063. http://dx.doi.org/10.1029/2002GC000345.

Stott, L., Timmermann, A., Thunell, R., 2007. Southern Hemisphere and deep-sea warming led deglacial atmospheric $\mathrm{CO}_{2}$ rise and tropical warming. Science 318, 435-438.

Strub, P.T., Mesias, J., Montecino, V.B., Rutllant, J.C., Marchant, C.C., 1998. Coastal ocean circulation off western South America. In: Robinson, A.R., Brink, K.H. (Eds.), The Sea, vol. 11. John Wiley, New York, pp. 273-314.

Sugden, D.E, Bentley, M.J. Fogwill, C.J. Hulton, N.RJ., McCulloch, R.D., Purves, R.S, 2005. Late-glacial glacier events in southernmost South America: a blend of 'northern' and ‘southern' hemispheric climate signals? Geografiska Annaler 87A (2), 273-288.

Sugden, D.E., McCulloch, R.D., Bory, A.J.-M., Hein, A.S., 2009. Influence of Patagonian glaciers on Antarctic dust deposition during the last glacial period. Nature Geoscience 2, 281-285.

Timmermann, A., Timm, O., Stott, L., Menviel, L., 2009. The roles of $\mathrm{CO}_{2}$ and orbital forcing in driving Southern Hemispheric temperature variations during the last 21000 yr. Journal of Climate 22, 1626-1640.

Trull, T., Rintoul, S.R., Hadfield, M., Abraham, E.R., 2001. Circulation and seasonal evolution of polar waters south of Australia: implications for iron fertilization of the Southern Ocean. Deep Sea Research Part II: Topical Studies in Oceanography 48, 2439-2466.

Valdenegro, A., Silva, N., 2003. Caracterización oceanográfica física y química de la zona de canales y fiordos australes de Chile entre el Estrecho de Magallanes y Cabo de Hornos (Cimar 3 Fiordos). Ciencia y Tecnología del Mar 26 (9), 19-60.

Weninger, B., Jöris, O., Danzeglocke, U., 2009. CalPal-2007. Cologne Radiocarbon Calibration \& Palaeoclimate Research Package. http://www.calpal.de/ (accessed 2009-01-10).

Yokoyama, Y., Esat, T.M., 2011. Global climate and sea level-enduring variability and rapid fluctuations over the past 150,000 years. Oceanography $24,54-67$. 